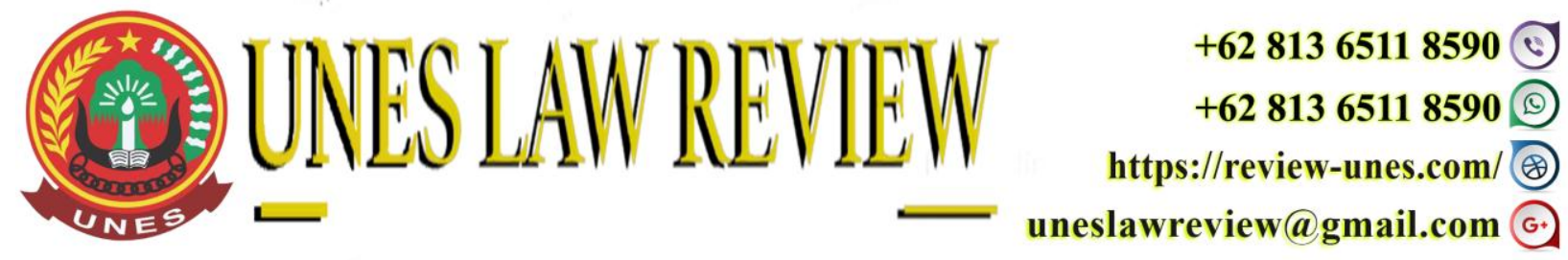

DOI: https://doi.org/10.31933/unesrev.v4i1

Diterima: 29/09/2021, Diperbaiki: 03/10/2021, Diterbitkan: 05/10/2021

\title{
ANALISIS YURIDIS TINDAK PIDANA ILLEGAL LOGGING DITINJAU DARI PERBANDINGAN HUKUM INDONESIA, FILIPHINA, DAN MALAYSIA
}

\author{
Reviansyah Erlianto ${ }^{1}$, Galih Raka Siwi ${ }^{2}$, Wahyu Donri ${ }^{3}$ \\ ${ }^{1)}$ Fakultas Hukum Universitas Singaperbangsa Karawang \\ Email: revianlaw19@gmail.com \\ ${ }^{2)}$ Fakultas Hukum Universitas Singaperbangsa Karawang \\ Email: galihrakas112@gmail.com \\ 3) Fakultas Hukum Universitas Singaperbangsa Karawang \\ Email: wahyu.donri@fh.unsika.ac.id
}

Corresponding Author: Penulis ${ }^{1}$

\begin{abstract}
Globalization certainly has an impact on developments in every country, therefore forest conversion activities are carried out with government permission. In practice, several acts of excessive forest exploitation were found which were classified as criminal acts of illegal logging. The purpose of this study is to understand the existence of the state in forest monitoring and management, and to compare illegal logging crimes in Indonesia, Malaysia, and the Philippines in terms of the laws and regulations of each country. The normative legal research method is in the form of secondary data, the author makes a legal comparison between the laws of the three countries collected through literature study. The results obtained, that the crime of illegal logging is a large and organized crime, in their regulations have condemned all actions related to environmental destruction including illegal logging, weak law enforcement is a factor that causes this crime to be repeated every year.
\end{abstract}

Keywords: Illegal Logging, Environment, Comparative Law

\section{ABSTRAK}

Globalisasi tentu membawa dampak terhadap perkembangan pembangunan pada setiap negara, khususnya pada daerah yang memiliki potensi sumber daya yang berlimpah, oleh karena itu dilaksanakannya kegiatan pengalihfungsian hutan yang dilakukan atas izin negara melalui pemerintah. Namun dalam pratiknya ditemukan beberapa tindakan yang dilakukan sebagian oknum untuk mengeksploitasi kawasan hutan secara berlebih demi meraup keuntungan yang nantinya diklasifikasikan kedalam tindak pidana pembalakan liar (Illegal Logging). Tujuan 
dilakukan penelitian ini ialah memahami eksistensi negara dalam pengawasan dan pengelolaan kawasan hutan, serta membandingkan tindak pidana pembalakan liar di Indonesia, Malaysia, dan Filiphina ditinjau dari peraturan perundang-undangan pada masing-masing negara. Metode penelitian hukum normatif berupa data sekunder, serta penulis melakukan perbandingan hukum antara hukum Indonesia, Malaysia, dan Filiphina yang dikumpulkan melalui studi kepustakaan. Hasil yang diperoleh, bahwa tindak kejahatan pembalakan liar merupakan tindak pidana yang besar dan terorganisir, ketiga negara dalam regulasinya telah mengutuk semua tindakan yang berhubungan dengan perusakan lingkungan termasuk pembalakan liar, lemahnya penegakan hukum menjadi faktor penyebab kejahatan ini terulang setiap tahunnya.

Kata Kunci: Pembalakan Liar, Lingkungan, Perbandingan Hukum

\section{PENDAHULUAN}

Hutan merupakan bagian yang tidak dapat dipisahkan dari kehidupan makhluk hidup, tempat tinggal dari separuh spesies yang ditemukan di darat berada di hutan, hubungan antara keduanya telah berlangsung selama berabad-abad. Hutan dimaknai pula sebagai sumber daya alam yang memiliki nilai ekonomis, religius, sosial, dan budaya. Oleh karena itu hutan dan makhluk hidup memiliki hubungan ketergantungan satu sama lain (Damayatanti, 2011). Peran hutan dalam kehidupan manusia tentu tidak diragukan lagi, namun masih banyak di luar sana yang belum memahami dan mensyukuri peran hutan bagi kehidupan. Melonjaknya angka deforestasi global merupakan cerminan dari menurunnya kualitas pengelolaan lingkungan pada beberapa negara dunia, bahkan dalam 35 tahun terakhir merupakan titik kritis hingga mendegradasi fungsi-fungsi utama hutan, hal itu diikuti dengan dampak yang ditimbulkan melalui beberapa bencana alam yang terjadi karena penurunan kualitas pengelolaan lingkungan. Tentu hal ini bukanlah masalah yang dapat dianggap remeh. Kerusakan alam merupakan bencana yang besar dan berkelanjutan, dampak dari kerusakan alam dapat dirasakan pada masa mendatang bahkan dapat mengakibatkan kerugian materi hingga korban jiwa (Tanjung, N. S. et al., 2017).

Dalam peraturan perundang-undangan pengertian hutan didefinisikan sebagai lahan berupa suatu kesatuan ekosistem sumber daya alam yang didominasi pepohonan dalam komonitas alam yang saling berketergantungan satu dan lainnya. (Lihat Pasal 1 Ayat (1) UU Nomor 18 Tahun 2013). Hutan Indonesia sejak dahulu menyimpan keanekaragaman jenis populasi flora dan fauna, beberapa spesies flora dan fauna langka ditemukan di Indonesia. Bahkan kawasan hutan Indonesia telah diakui oleh organisasi kehutanan dunia yang dikenal dengan Center for International Forestry Research (CIFOR), sebagai "paru-paru dunia" atas sumbangsihnya dalam menghasilkan 30-40\% cadangan oksigen bumi (Dominique Lyons, 2019). Meski demikian sayangnya anugerah tersebut tidak sepenuhnya dijaga dan dimanfaatkan sebaikbaiknya. Tidak sedikit populasi spesies flora maupun fauna yang perlahan mengalami kepunahan akibat kesalahan metode dalam alih fungsi hutan dan eksploitasi terhadap hutan yang berlebih.

Memang tidak bisa kita pungkiri bahwa setiap pengembangan pembangunan tentu membawa dampak terhadap perubahan lingkungan terutama sumber daya hutan. Meski beberapa metode dalam pengalihfungsian hutan telah dilakukan, seperti reboisasi dan penebangan dengan 
sistem tebang pilih, untuk tetap menjaga keseimbangan alam. Pengalihfungsian hutan sendiri dapat dikatergorikan kedalam perbuatan perusakan lingkungan selama kegiatan tersebut dilakukan tidak sesuai dengan izin bahkan tidak memiliki izin pelaksanaan dari otoritas yang berwenang. Hal itu dikarenakan tindakan pengalihfungsian tidak mempertimbangkan dampak kerusakan lingkungan yang ditimbulkannya, dengan kata lain tindakan tersebut menimbulkan perubahan langsung atau tidak langsung terhadap lingkungan hidup sehingga melampaui kriteria baku kerusakan lingkungan hidup (Lihat Pasal 1 Ayat (13) s.d. (17) UU Nomor 32 Tahun 2009). Dalam praktiknya terdapat beberapa oknum yang melakukan perusakan lingkungan atau eksploitasi hutan secara ilegal, salah satunya ialah bentuk tindak kejahatan pembalakan liar (Illegal Logging).

Pengertian kegiatan Illegal Logging sejatinya tidak memiliki definisi secara tegas dan terperinci dalam peraturan perundang-undangan, dikenal pula dengan istilah pembalakan liar, merupakan rangkaian tindakan penebangan atau pembalakan, pengolahan, hingga pendistribusian kayu (baik ekspor-impor) yang tidak memiliki izin yang sesuai dari otoritas yang berwenang sehingga tidak sah dan bertentangan dengan hukum karena dipandang sebagai suatu perbuatan merusak sumber daya hutan. Dengan kata lain Illegal Logging merupakan rangkaian kegiatan dalam rangka pemanfaatan dan pengelolaan hasil hutan kayu yang bertentangan dengan hukum serta memiliki potensi merusak kelestarian hutan (Bawono, B. T. \& Mashdurohatun, 2021). Dalam regulasi Kehutanan Republik Indonesia, pembalakan liar (Illegal Logging) dapat digolongkan kedalam suatu tindakan menebang, menerima, membeli maupun menjual, menerima titipan, menyimpan, maupun memiliki hasil hutan tanpa memiliki hak atau izin dari pejabat yang berwenang (menafsirkan berdasarkan isi Pasal 50 Ayat (3) huruf e dan f Undang-Undang No. 41 Tahun 1999 Tentang Kehutanan).

Di Indonesia praktik pembalakan liar sejatinya merupakan kejahatan yang dapat digolongkan kedalam tindak kejahatan yang terorganisir, dimana umumnya dilakukan oleh sebagian oknum yang sebenarnya memiliki izin resmi dari pemerintah dalam melakukan penebangan hutan, seperti halnya pemegang izin konsensi Hak Penguasa Hutan (HPH). Dimana terdapat beberapa pihak yang turut terlibat dalam penebangan liar ini, tidak hanya pemegang izin penebangan hutan, buruh penebang kayu, pemilik modal, penjual, hingga pembeli. Melainkan pada nyatanya terdapat beberapa oknum aparat serta tokoh masyarakat yang telah berkerjasama dibaliknya. Hal ini tentu mengakibatkan kerugian yang besar bagi negara dalam segi materiil maupun immaterial (Pranata et al., 2021). Tindakan tersebut merupakan salah satu bentuk tindakan dari perusakan sumber daya hutan, ini membuktikan bahwa belum efektifnya penegakan aturan hukum terkait pencegahan dan perlindungan perusakan hutan di Indonesia.

Beberapa negara yang berada disekitar garis khatulistiwa memiliki iklim tropis, salah satunya negara-negara di wilayah Asia Tenggara, hal tersebut berdampak pada kesuburan tanahnya. Indonesia merupakan negara yang memiliki anugerah melimpah akan kekayaan alamnya, sumber daya alam merupakan salah satu komponen penunjang keberlangsungan mahkluk hidup yang perlu dijaga dan dilestarikan. Salah satu kompenen sumber daya alam ialah hutan. Hutan sebagai anugerah serta amanah Tuhan YME merupakan kekayaan alam yang 
dimiliki oleh negara dan tak ternilai harganya. Oleh sebab itu hutan harus diurus, dimanfaatkan, serta dijaga kelestariannya (konsiderans Undang-Undang Republik Indonesia No. 41 Tahun 1999 Tentang Kehutanan). Hal tersebut tentu sejalan dengan amanat konstitusional Indonesia, "Bumi, air, dan kekayaan alam dikuasai oleh negara serta dipergunakan untuk kemakmuran rakyat" (Lihat Pasal 33 Ayat (3) Undang-Undang Dasar 1945). Artinya hutan merupakan kekayaan alam yang dimiliki oleh negara serta wajib diurus, dimanfaatkan, dan dilestarikan untuk kemakmuran rakyat.

Permasalahan perusakan lingkungan bukan hanya merupakan persoalan domestik semata, melainkan telah menjadi persoalan dunia, hal ini terjadi karena menyangkut konteks lingkungan dimana penyebab atau sumber dan akibat yang ditimbulkan berdampak pada keseimbangan alam global. Tindak kejahatan pembalakan liar (Illegal Logging) bukan hanya marak terjadi di Indonesia, pada Februari 2021 Departemen Kehutanan Pahang telah menggagalkan penebangan illegal di Bentong, Malaysia (Radzi Razak, 2021). Pada Desember 2020 Departemen Lingkungan Hidup dan Sumber Daya Alam (DENR) di Samar, Filiphina, telah memberikan konfirmasi akan maraknya pembalakan liar di Pegunungan Samar (Abrematea, 2020). Setiap tahunnya permasalahan pembalakan liar terus menjadi persoalan yang belum juga tuntas, motif dan alasannya hampir serupa pada setiap negara, ialah pelanggaran izin atau lisensi pemanfaatan kawasan hutan dan meraup keuntungan sebesar-besarnya dari hasil hutan tanpa memperhatikan keseimbangan alam serta dampak yang ditimbulkan.

Di Indonesia mekanisme tindakan yang dapat digolongkan ke dalam pembalakan liar (Illegal Logging) memiliki keterkaitan dengan beberapa peraturan perundang-undangan lainnya. Diantaranya, Kitab Undang-Undang Hukum Pidana (KUHP), Undang-Undang Nomor 41 Tahun 1999 Tentang Kehutanan, Undang-Undang No. 39 Tahun 2014 Tentang Perkebunan, UndangUndang No. 32 tahun 2009 Tentang Perlindungan dan Pengelolaan Lingkungan Hidup, serta Undang-Undang 18 Tahun 2013 Tentang Pencegahan Pemberantasan Perusakan Hutan. Sehubungan dengan hukum pidana Indonesia yang mengenal suatu asas preferensi, Lex Specialis Derogat Legi Generali. Digunakan apabila dalam suatu peristiwa hukum melanggar atau berkaitan dengan beberapa peraturan maka akan ditentukan hukum mana yang lebih didahulukan untuk diberlakukan (Agustina, 2015). Maka dari itu dalam tulisan ini penulis hanya memperbandingkan peraturan antara masing-masing negara (Indonesia, Malaysia, dan Filiphina) yang berhubungan dengan kehutanan, lingkungan hidup, dan pencegahan pemberantasan perusakan hutan $(\mathrm{P} 3 \mathrm{H})$.

Sehubungan dengan Konstitusi Federal Malaysia, bahwa semua negara bagian Malaysia memiliki yurisdiksi kekuasaan atas penataan, pengelolaan, peruntukan, dan penggunaan pada masing-masing sumber daya hutannya, artinya masing-masing negara bagian memiliki aturan tersendiri terhadap aturan kehutanannya. Namun terdapat dua sumber hukum utama terkait kebijakan peraturan kehutanan di Malaysia, yaitu Laws of Malaysia Act 313-National Forestry Act 1984 dan The National Forestry Policy of 1978 (Forest Legality Initiative, 2013). Maka dalam penelitian ini penulis hanya membandingkan kedua sumber hukum utama negara federal 
Malaysia. Sedangkan Filiphina membentuk peraturan kehutanannya dalam Presidential Decree No. 705 Forestry Reform Code of The Philippines dan Republic Act No 3701.

Permasalahan pembalakan liar yang terjadi di Indonesia, Malaysia, dan Filiphina merupakan gambaran kecil dari bentuk perusakan lingkungan yang terjadi terus menerus yang dampaknya akan dirasakan oleh generasi mendatang. Hal tersebut diakibatkan oleh rendahnya kepedulian masyarakat terhadap kelestarian lingkungan serta terdapat celah kesempatan bagi sebagian oknum yang mengambil keuntungan dari tindak kejahatan tersebut. Serta kurangnya keseriusan pemerintah dalam menangani permasalahan tersebut. Dengan kata lain penerapan aturan hukum terkait perlindungan lingkungan pada masing-masing negara masih belum mencapai pada tingkat yang diharapkan.

Berkaitan dengan tindak kejahatan pembalakan liar (Illegal Logging), beberapa penelitian terdahulu yang telah dilakukan seperti beberapa jurnal terkait "Penegakan hukum terhadap pelaku penebangan liar", "Akibat hukum penebangan hutan secara liar", dan lainnya. Persoalan yang diidentifikasikan dalam jurnal ini relatif belum banyak diulas lebih dalam jurnal-jurnal sebelumnya, dimana dalam jurnal ini menggunakan perspektif perbandingan hukum antara Indonesia, Malaysia, dan Filiphina. Dalam penelitian ini akan membandingkan persamaan dan perbedaan penegakan hukum terkait tindak kejahatan pembalakan liar pada ketiga negara tersebut. Tindakan pencegahan dan perlindungan perusakan sumber daya hutan merupakan upaya yang harus dilakukan semua negara sebagai masyarakat dunia agar kelestarian dan keseimbangan alam tetap terjaga. Lantas bagaimana kewajiban negara sebagai pihak yang mempunyai wewenang dan tanggung jawab dalam upaya perlindungan dan pengelolaan sumber daya hutan menurut konstitusi, hingga persamaan dan perbedaan hukum antara Indonesia, Malaysia, dan Filiphina dalam melakukan perlindungan sumber daya hutan.

Hutan disebut sebagai "paru-paru dunia" yang memiliki peranan yang sangat penting, ia berfungsi sebagai komponen pengatur cuaca yang sangat signifikan, selain itu di dalamnya terdapat keanekaragaman tumbuhan dan satwa yang berfungsi sebagai penyeimbang keberlangsungan alam (Supriadi, 2010). Ketidakseimbangan ekosistem tentu berpengaruh pada menurunnya pasokan oksigen bumi yang tentu berakibat besar bagi global. Oleh karena itu tujuan penulisan ini dimaksudkan agar pembaca memahami esensi hutan serta membandingkan aturan hukum terkait pencegahan dan pemberantasan perusakan hutan antara negara Indonesia, Malaysia, dan Filiphina. Sudah sepatutnya kita lebih mensyukuri serta menjaga kelestarian hutan, apabila keseimbangan alam tidak terjaga maka dampaknya akan dirasakan oleh generasi mendatang.

\section{METODE PENELITIAN}

Dalam melaksanakan penelitian ini penulis menggunakan metode penelitian hukum normatif, jenis data yang dikumpulkan merupakan data sekunder. Dalam penelitian ini penulis melakukan perbandingan hukum antara hukum Indonesia, Malaysia, dan Filiphina berkaitan dengan objek penelitian. Data sekunder diperoleh dalam bentuk data yang sudah jadi, berupa publikasi/laporan, peraturan perundang-undangan, serta sumber informasi elektronik lainnya (Benuf \& Azhar, 2020). 
Dalam Penelitian ini, data yang yang diperoleh menggunakan teknik pengumpulan data dengan cara melalui studi kepustakaan, sehingga mendapat beberapa bahan hukum dari dalam maupun luar negeri, antara lain: Peraturan perundang-undangan Indonesia (UU No. 18 Tahun 2013, UU No. 41 Tahun 1999, dan lain-lain), Peraturan Kehutanan Malaysia (Laws Of Malaysia Act 313-National Forestry Act 1984 dan The National Forestry Policy of 1978), Peraturan Kehutanan Filiphina (Presidential Decree No. 705 Forestry Reform Code Of The Philippines, Republic Act No 3701, dan The Chainsaw Act of 2002), publikasi beberapa jurnal nasional dan internasional, buku hukum, serta media informasi elektronik. Berdasarkan bahan hukum yang diperoleh, selanjutnya peneliti menganalisis, mengkaji, dan menyeleksi data dalam melakukan perbandingan hukum antara negara Indonesia, Malaysia, dan Filiphina. Supaya memperoleh hasil dari identifikasi masalah dalam penelitian ini, metode penelitian yang digunakan penulis berupa deskriptif kualtitatif dan perbandingan hukum serta penalaran secara deduktif.

\section{HASIL DAN PEMBAHASAN}

Eksistensi negara dalam pengawasan dan pengelolaan kawasan hutan menurut peraturan perundang-undangan antara Indonesia, Malaysia, dan Filiphina

Negara memiliki tanggung jawab terhadap pemenuhan kebutuhan setiap warga negaranya. Dalam menjalankan fungsi dan perannya, negara melalui pemerintah menetapkan suatu kebijakan publik yang berorientasi kepada kesejahteraan rakyat. Dalam menetapkan suatu kebijakan terdapat dua hal yang harus dijadikan pedoman, yaitu memecahkan permasalahan dan memenuhi kebutuhan sosial. Hal tersebut tentu berimplikasi pada perubahan sosial atau kesejahteraan rakyat, pada intinya fungsi dan peran negara dalam pembuat kebijakan publik: (1) Mengantisipasi, meminimalisir, atau memberikan solusi terhadap permasalahan sosial yang terjadi; (2) Negara memiliki peran sebagai penganyom rakyat, artinya negara memiliki tanggung jawab dalam memenuhi segala kebutuhan rakyat; dan (3) Fungsi negara dalam alokasi dan distribusi, artinya negara berkewajiban dalam menggali, mengalokasikan, dan mengembangkan segala sumber daya yang dimilikinya demi terpenuhinya kesejahteraan rakyat (Suryono, 2014). Oleh karena itu, dalam setiap pembuatan kebijakan publik, negara melalui pemerintah harus berpegang teguh pada kesejahteraan rakyat dan keadilan sosial. Negara memiliki peran yang sangat signifikan dalam menerapkan kebijakan publik, segala aturan atau regulasi yang ditetapkan oleh negara haruslah merupakan solusi dalam setiap permasalahan. Karena segala kebijakan tentu berdampak pula pada perubahan lingkungan sosial maupun lingkungan alam.

Salah satu bentuk upaya negara yang bertujuan dalam pemenuhan kebutuhan warga negaranya ialah dengan mengelola dan memanfaatkan segala sumber daya yang dimilikinya. Salah satu sumber daya yang merupakan anugerah dari Tuhan YME ialah sumber daya alam. Negara berhak menguasai sumber daya atau kekayaan alam yang ada di Indonesia sesuai amanat konstitusi Republik Indonesia (Konsiderans 33 Ayat (3) Undang-Undang Dasar 1945). Namun perlu digaris bawahi bahwa sumber daya alam yang tumbuh dan berkembang di bumi merupakan satu kesatuan ekosistem yang memiliki hubungan ketergantungan dengan semua makhluk hidup di bumi. Oleh karena itu, kita sebagai masyarakat bumi tentu memiliki kewajiban dalam menjaga 
dan melestarikan sumber daya alam. Salah satu upaya pelestarian ialah dengan melakukan konservasi sumber daya alam. Hal itu bertujuan agar sumber daya alam dapat tetap menjadi sumber dan penopang hidup bagi rakyat serta segala mahkluk hidup didalamnya. Pernyataan tersebut merupakan bentuk implikasi negara dalam memenuhi hak asasi serta hak konstitusional negara sesuai dengan amanat Pasal 28H Ayat (1) Undang-Undang Dasar Republik Indonesia. Menyatakan bahwa setiap orang memiliki hak untuk mendapatkan tempat tinggal, serta lingkungan hidup yang baik dan sehat (Listiyani et al., 2018).

Sumber daya alam hayati merupakan suatu kesatuan ekosistem yang terdiri dari beberapa unsur hayati yang berasal dari alam, terdiri dari sumber daya alam nabati dan sumber daya alam hewani. Hutan sendiri secara tersirat dapat digolongkan kedalam sumber daya alam hayati, oleh karena itu pelestarian hutan dapat digolongkan kedalam upaya konservasi sumber daya alam hayati. Dalam upaya tersebut, negara melalui pemerintah dan masyarakat memiliki tanggung jawab dalam konservasi sumber daya alam hayati sesuai dengan peraturan perundang-undangan (Lihat Pasal 1 Angka 1-3 dan Pasal 4 UU No. 5 Tahun 1990).

Hutan merupakan salah satu kekayaan alam yang memiliki segudang manfaat, pemanfaatan hutan dapat dilakukan dan dipergunakan bagi pengkehidupan bangsa. Eksplorasi hutan artinya memanfaatkan segala aspek yang terletak di hutan secara efektif dan efisien. Bentuk eksplorasi bukan hanya memanfaatkan hasil hutan saja, melainkan pemanfaatan kawasan, jasa lingkungan, dan nilai estetika hutan. Dengan adanya kegiatan ini diharapkan dapat meningkatkan dan memajukan kesejahteraan masyarakat serta merupakan salah satu bentuk upaya dalam pelestarian hutan. Dalam kegiatan pemanfaatan hutan tentu memerlukan kerjasama antara masyarakat setempat, pihak pemegang izin pemanfaatan, dan pemerintah selaku otoritas yang memiliki wewenang. Segala tindakan harus dilakukan sesuai prosedur dan regulasi, disinilah perlunya peran pemerintah sebagai badan pengawas hutan agar mengawasi segala bentuk ancaman perusakan hutan (Budi \& Subekti, 2021).

Setiap negara memiliki kekuasaan atas segala sumber daya yang dimilikinya, namun penguasaan yang dimaksud tidak sepenuhnya bahwa negara memiliki kepemilikan, melainkan kewenangan negara yang dilaksanakan oleh pemerintah dalam mengurus dan mengatur segala sesuatu terkait sumber dayanya (YULIANI \& Lusiah, 2015). Indonesia, Malaysia, dan Filiphina mengakui dalam peraturan perundang-undangannya bahwa hutan sepenuhnya merupakan aset negara, menjadi milik badan negara yang dipergunakan sebesar-besarnya untuk kemakmuran rakyat. Meliputi semua hasil hutan, yang terletak, tumbuh, dan berkembang dari hutan. Segala pemanfaatan sumber daya hutan dilakukan atas izin atau lisensi dari otoritas yang berwenang, serta diatur, dilindungi, dan dijamin oleh konstitusi. Penguasaan negara atas hutan artinya memberikan kewenangan kepada negara untuk mengatur, mengurus, dan menetapkan segala aturan yang berhubungan dengan hutan, kawasan hutan, hubungan hukum antara orang dengan hutan, serta segala perbuatan hukum mengenai kehutanan (Lihat Pasal 4 UU RI No. 41 Tahun 1999 dan Part IV Chapter 1 No. 14 Act 313- UU Kehutanan Nasional Malaysia). Pemanfaatan atas sumber daya hutan termasuk lahan hutan harus dimanfaatkan sebaik-baiknya untuk kepentingan publik. Segala bentuk pemanfaatan harus dilakukan secara tepat dan sistematis serta 
berorientasi pada kebutuhan negara, pembangunan dan pemajuan teknologi, dan kemakmuran rakyat.

Ketiga negara tersebut memiliki kebijakan dalam mengatur, mengurus, dan mengelola pemanfaatan dan penggunaan kawasan hutan kedalam suatu "izin penggunaan" atau disebut dengan "lisensi". Hal tersebut sejalan dengan pernyataan, "No person shall occupy or carry out any activity upon any land within a permanent reserved forest, unless he is the holder of a use permit." (Part IV Chapter 4 No. 32 Act 313, UU Kehutanan Nasional Malaysia) dan "No person may utilize, exploit, occupy, possess or conduct any activity within any forest land, or establish and operate any wood-processing plant, unless he has been authorized to do so under a license agreement, lease, license, or permit." (Section 20 Presidential Decree, Kode Reformasi Kehutanan Filiphina) (Lihat pula Pasal 23 s.d Pasal 29 UU Kehutanan Republik Indonesia). Disini negara berperan sebagai penyedia fasilitas melalui izin yang diberikan kepada perorangan atau badan usaha yang hendak memanfaatkan, memiliki, melakukan kegiatan, dan mengambil hasil hutan.

Dalam memanfaatkan segala hasil hutan negara tentu perlu mempertimbangkan dampak yang akan ditimbulkan terhadap kerusakan lingkungan. Sayangnya kenyataan yang terjadi di lapangan sungguh terbalik, penyebab kerusakan lingkungan pada masing-masing negara hampir serupa. Dimana permasalahan yang terjadi tentu menyangkut eksploitasi hutan secara berlebih, adanya peran para pemangku kepentingan (stakeholders) yang terlibat, serta buruknya upaya penanganan konservasi hutan (Sudiyono, 2008). Hal ini tentu bertentangan dengan kewajiban negara dalam merawat dan mengelola kawasan hutan yang dimilikinya. Disinilah peran negara sebagai otoritas yang memiliki kewajiban dalam melakukan upaya konservatif terhadap kawasan hutan, salah satu upaya konservasi ialah dengan melakukan reboisasi (reforestation).

Pemerintah Filiphina telah membuat kebijakan besar dalam rangka kegiatan reboisasi, melalui Republic Act of Philippines No. 10176, mewajibkan menanam satu pohon per tahunnya kepada setiap warga negaranya yang berusia diatas 12 tahun. Meski terdapat beberapa perbedaan kebijakan pada ketiga negara tersebut dalam pemberlakuan aturan kewajiban reboisasi, namun pada intinya negara tetap bertanggung jawab terhadap pengelolaan pemanfaatan kawasan hutan. Dalam menjalankan upaya reboisasi, pemerintah Indonesia menerapkan pemungutan biaya "dana reboisasi" kepada setiap pemegang izin usaha pemanfaatan hutan, yang nantinya dana tersebut akan disalurkan untuk mendanai pelaksanaan reboisasi, rehabilitasi, dan kegiatan pendukung lainnya. Kebijakan yang diambil Malaysia sejatinya hampir serupa dengan Indonesia, dimana para pemohon lisensi diwajibkan mempersiapkan perencanaan reboisasi pada saat mereka mengajukan permohonan lisensi, apabila persyaratan itu belum sempurna maka lisensi yang diberikan akan dicabut. Sedangkan, regulasi kehutanan Filiphina dalam melaksanakan, mengembangkan, dan menegakan reboisasi (reforestation) merupakan tanggung jawab dari biro pemerintahan (terdiri dari penggabungan semua instansi kehutanan yang disebut Biro Kehutanan Pengembangan/the Bureau of Forest Development).

Persamaan dan perbedaan tindak pidana pembalakan liar (Illegal Logging) antara Indonesia, Malaysia, dan Filiphina sesuai peraturan perundang-undangan 
Dalam pembahasan sebelumnya telah dibahas sejauh mana peran dan kontribusi negara terhadap kegiatan pemanfaatan, pengelolaan, dan pelestarian sumber daya alam hayati khususnya pada kawasan hutan sesuai dengan peraturan perundang-undangan. Dari pembahasan tersebut, maka diketahui bahwa negara memiliki kedudukan dan kekuasaan yang besar dalam menegakan hukum. Melalui peraturan perundang-undangan, negara memiliki hak dan kewajiban dalam mengendalikan segala sumber daya yang dimilikinya. Termasuk dalam menindak dan menghukum siapapun yang melanggar segala perbuatan yang dilarang oleh undang-undang. Hal tersebut tentu berlaku bagi semua negara di dunia, namun masih banyak kita temukan berbagai celah kekosongan hukum atau pelanggaran yang terjadi berulang kali meski adanya peraturan yang melarang tindakan tersebut. Salah satu tindak kejahatan yang marak terjadi di Indonesia, Malaysia, maupun Filiphina ialah tindak kejahatan pembalakan liar (Illegal Logging).

Kejahatan pembalakan liar ialah permasalahan dalam bidang kehutanan yang terjadi terus menerus dan terjadi pada setiap tahunnya. Banyak faktor yang menjadi penyebab tindak kejahatan pembalakan liar, salah satunya ialah fakta bahwa perdagangan sumber daya hutan menghasilkan keuntungan investasi yang sangat besar dengan modal yang relatif kecil. Dengan alasan tersebut dan dorongan kebutuhan ekonomi masyarakat menjadi salah satu pemicu adanya eksploitasi dan pengurangan sumber daya hutan secara besar-besaran melalui beberapa kegiatan yang tidak sesuai dengan peraturan kehutanan. Hal tersebut mengakibatkan menurunnya kualitas dan kuantitas sumber daya hutan (Narindrani, 2018).

Apabila berbicara mengenai pembalakan liar, tindakan itu bukan hanya terjadi di wilayah negara-negara berkembang, melainkan terjadi pada hampir semua negara di dunia yang memiliki kawasan hutan atau cagar alam. Tindakan pembalakan liar sejatinya merupakan suatu rangkaian tindakan yang melalui mekanisme panjang, dimana tindakan tersebut dilakukan secara sistematis dan terorganisir. Dilakukan secara sistematis artinya segala kegiatan yang dilakukan mulai dari persiapan, pelaksanaan, pendistribusian, hingga pemanfaatan/pengolahan dilakukan secara Illegal (tidak memiliki izin yang sah). Pertama, persiapan yang dilakukan berupa izin pemanfaatan kawasan hutan tidak sesuai atau bahkan tidak memiliki izin/lisensi. Kedua, dalam pelaksanaan penebangan pohon (Logging) dan lokasi pelaksanaan tidak sesuai dengan regulasi yang ditetapkan. Ketiga, proses pendistribusian atau pengangkutan barang tentu tidak memiliki izin karena ketidakcakapan status kelegalan kayu. Keempat pemanfaatan dan pengelolaan digolongkan tindakan illegal karena produk yang diolah merupakan barang yang diseludupkan dan tidak memiliki dokumen kelegalan. Sedangkan dikatakan terorganisir karena dalam pratiknya serangkaian tindak kejahatan tersebut tentu memerlukan kontribusi atau kerja sama dari beberapa pihak mulai dari proses pemotongan hingga pengelolaan dan penjualan. Artinya tindak pidana pembalakan liar merupakan suatu kejahatan yang besar dan sangat merugikan bagi lingkungan dan negara. Bahkan dalam Pasal 10 Undang-Undang RI Nomor 18 Tahun 2013, menyatakan apabila didapati suatu perbuatan atau perkara terkait perusakan hutan, maka pengajuan perkara tersebut harus didahulukan dari perkara lain agar secepatnya didapatkan penyelesaian. 
Pembalakan liar menurut hukum Malaysia secara langsung maupun tidak langsung berkaitan dengan beberapa hukum nasional, salah satunya Federal Constitution, National Land Code 1965 (Act 56), dan Penal Code (Act 574), namun dalam penelitian ini hanya memperbandingkan peraturan kehutanan dan perlindungan lingkungan pada masing-masing negara. Memang dalam UU kehutanan nasional Malaysia tidak secara tegas mengatur mengenai pembalakan liar (Illegal Logging). Namun segala kegiatan yang digolongkan kedalam rangkaian pembalakan liar telah dilarang di dalam regulasi kehutanan nasional Malaysia, berdasarkan Part VII No. 81, segala kegiatan yang menyebabkan kerusakan pada hutan termasuk mencari, mengambil, memindahkan hasil hutan dan sebagainya, pelaku akan diancam hukuman penjara atau hukuman denda yang dibayarkan kepada otoritas negara untuk membayar biaya pemulihan kawasan. Tambahan hukuman tergantung pula kepada peraturan kehutanan pada masing-masing negara bagian.

Kegiatan pembalakan liar yang terjadi pada beberapa negara memiliki motif yang hampir sama, faktanya beberapa kasus yang terungkap justru mereka telah memiliki izin/lisensi pemanfaatan kawasan hutan secara sah atau legal. Ditemukan beberapa kegiatan pembalakan yang berjalan sesuai kesepakatan yang diberikan oleh pemberi izin, namun tidak sedikit pula oknum yang justru memanfaatkan peluang agar dapat mengeksploitasi dan mengeruk keuntungan diluar kesepakatan dengan si pemberi izin. Tindakan seperti ini merupakan tindakan illegal yang digolongkan kedalam kegiatan perusakan hutan. Perusakan hutan menurut Republic Act of Philippines No. 3701 merupakan segala tindakan yang dilakukan seseorang secara langsung atau berkerjasama dengan sengaja yang menyebabkan kerusakan (berupa membakar, memotong, atau menghancurkan) pada kayu serta tumbuh-tumbuhan yang terdapat dihutan. Dalam regulasi tersebut, "penghuni kawasan" (actual occupants) atau setiap orang yang menempati, mengolah, dan memperoleh keuntungan dari kawasan hutan memiliki tanggung jawab terhadap hutan dan akan dimintai pertanggung jawaban apabila terdapat tindakan perusakan hutan. Sanksi yang akan dijatuhkan bagi pelanggar berupa hukuman pidana denda dan pidana penjara (Lihat Republic Act of Philippines No. 3701, huruf a s.d. c).

Apabila ditemukan terdapat tindakan yang tidak sesuai dengan izin yang diberikan, maka dalam Section 68 and 69 Presidential Decree, Kode Reformasi Kehutanan Filiphina. Diatur pula larangan memotong, mengumpulkan, dan/atau memungut kayu tanpa wewenang berdasarkan perjanjian lisensi, sewa, atau izin. Maka pelanggar menurut KUHP Filiphina dapat dituntut dengan perbuatan pencurian, serta akan dijatuhi sanksi pidana dan sanksi perdata. Sanksi pidana yang akan diterima pelaku, berupa hukuman penjara dan hukuman denda. Sedangkan sanksi perdata berupa pertanggung jawaban pembayaran sepuluh kali biaya sewa atau segala biaya yang timbul dari penggunaan dan rehabilitasi kawasan.

Permasalahan pembalakan liar di Filiphina memiliki keterkaitan pula dengan The Chainsaw Act of 2002 atau regulasi yang mengatur kepemilikan, penjualan, dan penggunaan gergaji mesin. Sejak diberlakukannya undang-undang ini, maka setiap orang atau badan yang memiliki atau menguasai gergaji mesin diharuskan mendaftarkan izin/lisensi melalui Petugas Lingkungan dan Sumber Daya Alam (CENRO). Berdasarkan Chapter IV No. 12.4, apabila 
ditemukan pengguna gergaji mesin yang menggunakan alatnya untuk menebang pohon dihutan secara illegal maka pelaku akan dijatuhi sanksi pidana dan sanksi denda, serta gergaji mesin akan disita oleh pemerintah. Sanksi yang akan jatuhkan kepada pelaku yang terbukti melakukan pembalakan liar (Illegal Logging) menurut ketiga undang-undang diatas akan dijatuhi pidana penjara dan pidana denda sesuai peraturan perundang-undangan Filiphina.

Dalam Kitab Undang-Undang Hukum Pidana (KUHP) Indonesia, Tindak kejahatan pembalakan liar (Illegal Logging) secara umum memiliki keterkaitan dengan beberapa unsur tindak pidana umum. Sehingga dapat digolongkan ke dalam beberapa bentuk kejahatan: (1) Pencurian, (2) Pengerusakan, (3) Penyeludupan, (4) Penggelapan, (5) Pemalsuan, dan (6) Penadahan (Pranata et al., 2021). Oleh sebab itu, dalam peraturan perundang-undangan Indonesia para pelaku atau pelanggar yang terlibat dalam tindak pembalakan liar dapat dijatuhi hukuman berupa sanksi pidana, sanksi administratif, dan sanksi perdata. Penerapan atau penjatuhan sanksi pidana dan sanksi administratif sesuai dengan undang-undang kehutanan, undang-undang perlindungan dan pengelolaan lingkungan hidup, undang-undang pencegahan dan pemberantasan perusakan hutan, serta dalam Peraturan Pemerintah Nomor 28 Tahun 1985 Tentang Perlindungan Hutan.

Penerapan sanksi pidana terhadap para pelaku perusakan hutan telah diatur dalam ketiga undang-undang di atas. Sanksi yang akan diterima berupa hukuman penjara, kurungan, denda, dan perampasan segala hasil kejahatan termasuk alat angkut yang dipergunakan. Penjatuhan sanksi terhadap para pelaku pembalakan liar diatur dalam ketentuan Pasal 78 Ayat (2) UndangUndang Kehutanan, Pasal 98 Undang-Undang Perlindungan dan Pengelolaan Lingkungan Hidup, dan Pasal 82 Ayat (1) Huruf c Undang-Undang Pencegahan dan Pemberantasan Perusakan Hutan. Sedangkan penjatuhan sanksi administratif terhadap para pelaku yang terbukti melakukan tindak kejahatan pembalakan liar diatur dalam ketentuan Pasal 80 Ayat (2) UndangUndang Kehutanan dan Pasal 76 ayat (1) Undang-Undang Perlindungan dan Pengelolaan Lingkungan Hidup. Negara melalui pemerintah memiliki wewenang dalam menjatuhkan sanksi administratif terhadap para pemegang izin usaha pemanfaatan kawasan, jasa lingkungan, hasil hutan, dan/atau izin pemungutan. Sehubungan dengan sanksi administratif diatas, sesuai dengan Pasal 80 Ayat (1) Undang-Undang Kehutanan dan Pasal 87 ayat (1) Undang-Undang Perlindungan dan Pengelolaan Lingkungan Hidup. Para pelaku kejahatan merupakan pihak yang bertanggung jawab atas kerusakan hutan, oleh sebab itu penjatuhan hukuman berupa perbuatan pertanggung jawaban dalam membayar kerugian berupa biaya pemulihan dan rehabilitasi kawasan hutan sesuai dengan dampak yang ditimbulkan dari tindakan tersebut. Penjatuhan sanksi diatas bertujuan agar para pelaku pembalakan liar dan perusakan sumber daya hutan memiliki kesadaran akan pentingnya fungsi dan peran hutan bagi keberlangsungan hidup.

\section{KESIMPULAN}

Tindak kejahatan pembalakan liar dapat digolongkan tindak kejahatan besar karena mekanisme dan jumlah keterlibatan banyak pihak didalamnya. Bahkan penulis beranggapan bahwa kejahatan pembalakan liar sebanding dengan kejahatan penyalahgunaan narkotika, karena 
dampak yang ditimbulkan oleh kerusakan lingkungan merupakan bencana yang besar dan efeknya dirasakan pada masa mendatang berupa bencana alam, perubahan suhu secara ektrim, kepunahan mahkluk hidup, dan lainnya. Dari penelitian ini diketahui bahwa permasalahan pembalakan liar merupakan suatu tindak kejahatan yang terjadi pada hampir di setiap negara, perlunya penegakan hukum yang mengatur dan memfasilitasi agar segala bentuk pemanfaatan kawasan hutan dapat tetap memperhatikan keseimbangan dan kelestarian hutan sebagai sumber daya alam hayati. Faktanya, masih lemahnya penegakan hukum pada masing-masing negara menyebabkan maraknya praktik pembalakan liar, banyak faktor dan kebijakan yang harus ditinjau kembali supaya dapat mengoptimalkan penegakan hukum. Serta perlunya partisipasi masyarakat dan peran pemerintah dalam upaya pelestarian sumber daya hutan.

Apabila kita memperbandingkan peraturan perundang-undangan yang mengatur terkait pembalakan liar (Illegal Logging) antara Indonesia, Malaysia, dan Filiphina. Ketiga negara tersebut melalui masing-masing regulasinya telah mengatur dan mengancam kepada siapapun yang melakukan segala bentuk perusakan lingkungan melalui beberapa sanksi pidana, perdata, maupun administratif. Namun dalam penerapannya sering kali tidak sejalan karena lemahnya penegakan hukum, adanya beberapa oknum penegak hukum yang justru turut andil dalam tindak kejahatan tersebut. Disinilah yang menjadi persoalan bagaimana lemahnya penegakan hukum yang terjadi disebabkan lemahnya integritas para penegak hukum.

\section{DAFTAR PUSTAKA}

Abrematea, N. (2020). Confirmed: lllegal logging in Samar. The Manila Times. https://www.manilatimes.net/2020/12/02/news/regions/confirmed-1llegal-logging-insamar/803646

Agustina, S. (2015). Implementasi Asas Lex Specialis Derogat Legi Generali Dalam Sistem Peradilan Pidana. Masalah-Masalah Hukum, 44(4), 503-510.

Bawono, B. T., \& Mashdurohatun, A. (2021). Penegakan Hukum Pidana Di Bidang Illegal Logging Bagi Kelestarian Lingkungan Hidup Dan Upaya Penanggulangannya. Jurnal Hukum, 26(2), 590-611.

Benuf, K., \& Azhar, M. (2020). Metodologi Penelitian Hukum sebagai Instrumen Mengurai Permasalahan Hukum Kontemporer. Gema Keadilan, 6(2), 20-33.

Budi, F., \& Subekti, R. (2021). Aspek Hukum Pemanfaatan Hutan Lindung Untuk Tempat Wisata. Jurnal Komunikasi Hukum (JKH), 7(2), 540-549.

Damayatanti, P. T. (2011). Upaya pelestarian hutan melalui pengelolaan sumberdaya hutan bersama masyarakat. KOMUNITAS: International Journal of Indonesian Society and Culture, 3(1)), 70-82.

Dominique Lyons. (2019). CIFOR dan Indonesia perbarui kerjasama melindungi hutan. Pusat Penelitian Kehutanan Internasional (CIFOR). https://forestsnews.cifor.org/60057/cifor-danindonesia-perbarui-kerjasama-melindungi-hutan?fnl=

Forest Legality Initiative. (2013). Malaysia. World Resources Institute. https://forestlegality.org/risk-tool/country/malaysia

Listiyani, N., Hayat, M. A., \& Mandala, S. (2018). Penormaan pengawasan izin lingkungan dalam pencegahan pencemaran dan kerusakan lingkungan hidup dalam eksploitasi sumber daya alam. Jurnal Media Hukum, 25(2), 217-227. 
Narindrani, F. (2018). Upaya Masyarakat dalam Pencegahan dan Pemberantasan Pembalakan Liar di Indonesia. Jurnal Penelitian Hukum De Jure, 18(2), 241-256.

Pranata, I. G. F. A., Yuliartini, N. P. R., \& Mangku, D. G. S. (2021). PENEGAKAN HUKUM TERHADAP PELAKU TINDAK PIDANA PENEBANGAN LIAR DI KABUPATEN BULELENG. Komunitas Yustisia, 4(1), 35-44.

Radzi Razak. (2021). Report: Pahang Forestry Dept foils illegal logging worth RM400,000 in Temerloh, Bentong. Malay Mail. https://www.malaymail.com/news/malaysia/2021/02/13/report-pahang-forestry-dept-foilsillegal-logging-worth-rm400k-in-temerloh/1949396

Sudiyono, S. (2008). DAMPAK EKSPLOITASI HUTAN DI FILIPINA TERHADAP KEHIDUPAN MASYARAKAT DAN LINGKUNGAN. Jurnal Masyarakat Dan Budaya, 10(1), 123-148.

Supriadi. (2010). Hukum Kehutanan Hukum Perkebunan di Indonesia. Sinar Grafika.

Suryono, A. (2014). Kebijakan publik untuk kesejahteraan rakyat. Transparansi: Jurnal Ilmiah Ilmu Administrasi, 6(2), 98-102.

Tanjung, N. S., Sadono, D., \& Wibowo. (2017). Tingkat partisipasi masyarakat dalam pengelolaan Hutan Nagari di Sumatera Barat. Jurnal Penyuluhan, 13(1), 14-30.

YUlIANI, F., \& Lusiah, S. (2015). Pengawasan Pelestarian Hutan Lindung oleh Dinas Kehutanan Dan Perkebunan Kabupaten Indragiri Hilir. Riau University.

Undang-Undang Dasar 1945

Undang-Undang Republik Indonesia Nomor 18 Tahun 2013 tentang Pencegahan dan Pemberantasan Perusakan Hutan.

Undang-Undang Republik Indonesia Nomor 41 Tahun 1999 tentang Kehutanan.

Undang-Undang Republik Indonesia Nomor 32 Tahun 2009 tentang Perlindungan dan Pengelolaan Lingkungan Hidup.

Peraturan Pemerintah Nomor 28 Tahun 1985 tentang Perlindungan Hutan.

Laws of Malaysia Act 313-National Forestry Act 1984.

Presidential Decree No. 705 Forestry Reform Code Of The Philippines.

Republic Act of Philippines No. 3701.

The Chainsaw Act of Philippines 2002. 